\title{
THE ANTINOMY OF TELEOLOGICAL JUDGMENT
}

\author{
INA GoY
}

\section{INTRODUCTION}

$\mathrm{T}$ HE antinomy of teleological judgment $(\$ \S 69-78)$ is one of the most controversial passages of Immanuel Kant's Critique of the Power of Judgment. Having developed the idea of a twofold explanation of organized beings by mechanical and teleological natural laws in $\S \S 61-68$, Kant raises the question in $\S \S 69-78$ of whether higher order mechanical and teleological natural laws, which unify the particular empirical laws of organized beings, might pose an antinomy of conflicting principles within the power of judgment. The first controversial questions is, what this conflict is about: ${ }^{1}$ is it an antinomy between (1) subjective regulative maxims of the reflecting power of judgment, or a conflict between (2) objective constitutive principles of the determining power of judgment, ${ }^{2}$ or is it an antinomy (3) between an objective constitutive principle of the determining power of judgment and a subjective regulative maxim of the reflecting power of judgment, ${ }^{3}$ or does the antinomy consist (4) in a confusion of a pair of subjective regulative maxims of the reflecting power of judgment and a pair of objective constitutive principles of the determining power of judgment? ${ }^{4}$ In this paper, I will defend the view that the antinomy consists in an apparent conflict between mechanical and teleological natural laws as regulative maxims of the reflecting power of judgment ${ }^{5}$ that can be discovered and resolved by means of Kant's critical method.

\footnotetext{
${ }^{1}$ For detailed discussions of versions of the antinomy in the literature, see also M. Frank, V. ZANetTI, Dialektik der teleologischen Urteilskraft, in I. KANT, Schriften zur Ästhetik und Naturphilosophie, Frankfurt a.M., Suhrkamp, 2001, III, pp. 1286-1306: 1288-1289, and M. QuARFOOD, The Antinomy of Teleological Judgment, in Transcendental Idealism and the Organism, Stockholm, Almquist \& Wiksell, 2004, pp. 160-208: 160-166. I restrict my own reconstruction to those four versions of an antinomial conflict, which I consider to be the most compelling ones.

2 This is the dominant interpretation among the earlier generation of interpreters (Adickes, Stadler, Körner, Ewing, Cassirer, Baumanns, Eisler, Engels, and Erdmann). For a brief survey, see P. McLaughlin, Die Antinomie der Urteilskraft, Bonn, Bouvier, 1989, Engl. transl. Kant's Critique of Teleology in Biological Explanation. Antinomy and Teleology, Lampeter, Edwin Mellon Press, 1990, pp. 137-145, and E. Watkins, Die Antinomie der teleologischen Urteilskraft und Kants Ablehnung alternativer Teleologien ( $\$ \S 69-73)$, in Immanuel Kant. Kritik der Urteilskraft, ed. by O. Höffe, Berlin, Akademie Verlag, 2008, pp. 241-258: 254.

3 Several commentators wonder why Kant interprets mechanical laws as regulative principles in the "Dialectic» of the Critique of the Power of Judgment and not as constitutive principles as in the Critique of Pure Reason and the Metaphysical Foundations of Natural Science.

${ }^{4}$ This is Quarfood's line of thought (The Antinomy of Teleological Judgment, pp. 160-208 and The Antinomy of Teleological Judgment: What It Is and How It Is Solved, in Kant's Theory of Biology, ed. by I. Goy, E. Watkins, BerlinBoston, de Gruyter, 2014, pp. 167-184). He thinks that - although mechanism and teleology are regulative maxims - we are inclined to take them constitutively, that is, that we are inclined to ascribe ontological commitments to those claims. The resolution of the antinomy consists partly in the avoidance of this slip into ontological demands. For arguments against this reading, see H. E. Allison, Kant's Antinomy of Teleological Judgment, in Kant's "Critique of the Power of Judgment»: Critical Essays, ed. by P. Guyer, New York, Rowman and Littlefield Publishers, 2003 (orig. 1991), pp. 219-236: 219-220.

${ }^{5}$ I share this view with other contemporary interpreters who also tend to see the antinomy as a conflict between subjective regulative maxims of reflecting judgment, even though for different reasons, see H. E. ALLison, Kant's Antinomy of Teleological Judgment and H. Ginsborg, Kant's Biological Teleology and its Philosophi-
} 
The second controversial question concerns Kant's resolution of the antinomy. ${ }^{1}$ Several suggestions have been made in the literature: does it simply consist in the detection of the confusion about both kinds of natural laws as regulative and constitutive principles; ${ }^{2}$ or does it consist in a supersensible that justifies the unity and unification of both kinds of natural laws - but if so, what kind of supersensible is it? Is it an intuitive understanding, ${ }^{3}$ or an indeterminate supersensible ground of nature, or a conjunction of both $?^{4}$ Or does the resolution of the antinomy consist in a unifying principle for our human judgment only, for instance, in the hierarchy of the two kinds of laws? $?^{5}$

In this paper, I will defend the view that Kant presupposes the idea of a supersensible that represents the unity of both kinds of natural laws and justifies the unification of both kinds of natural laws in our human power of judgment. ${ }^{6}$ As a first step, I would like to distinguish three notions that Kant uses when he talks about the supersensible: (1) the subjective idea of a divine artisan $(\S \S 74-75, \S 85, \S 91),(2)$ the subjective idea of an intuitive understanding ( $\$ \S 76-77)$, and (3) the subjective idea of an underdetermined, supernatural ground of nature $(\$ 78)$. I will show how each of these notions accounts for the unity of both kinds of natural laws. After this, I will discuss possible correlations between these three notions: in my opinion, the textual basis of the third Critique alone does not suffice to clarify their relationship. However, notes from Kant's lectures on rational and natural theology from the 1780s encourage an inclusive reading, in which the intuitive understanding is exactly the understanding of the divine artisan, which is effective as a supernatural ground of

cal Significance, in The Blackwell Companion to Kant, ed. by G. Bird, Oxford, Oxford University Press, 2006, pp. 455-469; E. Watkins, The Antinomy of Teleological Judgment, «Kant Yearbook», I, 2009, pp. 197-221; A. BreitenВАС , Die Analogie von Vernunft und Natur. Eine Umweltphilosophie nach Kant, Berlin-New York, de Gruyter, 2009, pp. 109-131; P. McLaughlin, Mechanical Explanation in the "Critique of the Teleological Power of Judgment", in Kant's Theory of Biology, pp. 149-166, and even though they provide different answers to the resolution of the antinomy.

1 A clearly written overview and criticism of significant recent interpretations of the resolution of the antinomy (McLaughlin, Förster, and Ginsborg) can be found in E. Watkins, The Antinomy of Teleological Judgment. However, Watkins is hesitant to offer his own resolution of the antinomy. His final word is a challenge of the best solutions available so far.

2 The detection of the confusion of regulative and constitutive principles is required in Quarfood's (The Antinomy of Teleological Judgment: What It Is and How It Is Solved) resolution of the antinomy.

${ }^{3}$ See E. Förster, Die Bedeutung von $\S \S 76,77$ der Kritik der Urteilskraft für die Entwicklung der nachkantischen Philosophie, "Zeitschrift für philosophische Forschung", LVI, 2, 2002, pp. 170-190, and Teil II, LVI, 3, pp. 321-345; Von der Eigentümlichkeit unseres Verstandes in Ansehung der Urteilskraft ( $\$ \S 74-78)$, in Immanuel Kant. Kritik der Urteilskraft, pp. 259-274; Die 25 Jahre der Philosophie, Frankfurt a.M., Klostermann, 2011, pp. 149-160; M. QUARFOoD, The Antinomy of Teleological Judgment, pp. 177-191; The Antinomy of Teleological Judgment: What It Is and How It Is Solved). Frank-Zanetti (Dialektik der teleologischen Urteilskraft, pp. 1292-1304) describe the intuitive understanding as the older and earlier resolution of the antinomy in $\S \S 76-78$ beside a younger and later resolution in $\S \S$ 69-75, which they find less convincing. More recently, Ph. Huneman, Purposiveness, Necessity, and Contingency, in Kant's Theory of Biology, pp. 185-202, argues that the intuitive understanding provides the resolution of the antinomy since it explains the necessity of the contingent features of the empirical laws of nature.

${ }^{4}$ Allison (Kant's Antinomy of Teleological Judgment, p. 230) claims that the unification of teleological and mechanical laws is granted by an indeterminate supernatural ground that can be accessed by the intuitive understanding.

5 See H. Ginsborg, Kant's Biological Teleology, pp. 461-462, and A. Breitenbach, Die Analogie von Vernunft und Natur, pp. 124-131.

${ }^{6}$ In the third Critique Kant gives no specific argument to explain why such a supersensible ground is necessary at all. I think the ultimate reason for Kant's assumption is his believe in a teleological unity of all things. 
nature. An inclusive reading also allows a consistent connection of the resolution of the antinomy in $\$ \S 74-78$ of the «Dialectic of the Teleological Power of Judgment» and the discussion of the divine artisan as a supersensible ground of the unity of both kinds of natural laws in the "Methodology of the Teleological Power of Judgment», especially in $\S 85$ (on physicotheology) and in the "Appendix» to $\S 91$. The consistency between these two passages is an interpretative requirement that existing interpretations of the antinomy fail to fulfill.

Then, I will investigate the extent to which the unity of both kinds of natural laws in the supersensible accounts for the unification of both kinds of natural laws in our human power of judgment. ${ }^{1}$ The fact that the natural laws are free of contradictions in the intuitive understanding of a divine artisan makes clear that the antinomial conflict just appears in our human power of judgment and in nature as it appears to us. But if the divine intuitive understanding is different from the human understanding, which is a discursive understanding, what does it help to know that both kinds of natural laws are free of antinomies in the divine understanding? I will argue that, according to Kant, the capacity of a unification of both kinds of natural laws in our human power of judgment is rooted in the unity of both kinds of natural laws in the divine understanding since Kant presupposes a regulative idea of creation. The unity of both kinds of laws in a divine understanding accounts for their unification in our human understanding and in nature as it appears to us since our human understanding and nature as it appears to us are created. While the divine intuitive understanding is perfect and uncreated and, thus, capable of a representation of the unity of both kinds of natural laws, the human discursive understanding is imperfect and created; it is capable only of the representation of the unification of both kinds of natural laws in form of a hierarchy of laws. - Finally, I will point to the fact that Kant embeds the regulative idea of the divine artisan into a richer regulative idea of God in $\$ \S 86-91$ that is perfect not only with regard to its theoretical but also to its practical capacities and that not only represents the unity of both kinds of natural laws but also the unity of natural and moral laws.

\section{The Antinomy of Teleological Judgment}

The antinomy of teleological judgment is supposed to arise when human beings make judgments about organized beings and thereby subsume the manifold and dissimilarity of particular empirical characteristics of natural beings under particular empirical laws and those particular empirical laws under higher order, unifying laws of nature. Since it could happen that they choose two contradictory higher order natural laws - namely mechanical and teleological laws - that form an antinomy. But why do human beings need such unifying higher order natural laws at all if they threaten them with antinomies and contradictions? Kant's answer is that they allow an investigation of particular appearances in nature and, in addition, render possible an interconnected experiential cognition of organized nature as a whole (KU, AA v 183.14-185.22). I argue that on the surface Kant's approach might be understood as sug-

\footnotetext{
${ }^{1}$ See M. Quarfood, The Antinomy of Teleological Judgment, p. 191.
} 
gesting one of the following four readings of a threatening conflict between the higher order laws of nature:

The antinomy (1) appears between two regulative subjective maxims that the reflecting power of judgment applies as higher order laws when it tries to unify the dissimilarities of the empirical laws of nature.

Thesis: "All generation of material things and their forms must be judged as possible in accordance with merely mechanical laws».

Antithesis: «Some products of material nature cannot be judged as possible according to merely mechanical laws (judging them requires an entirely different law of causality, namely that of final causes)". ${ }^{1}$

(KU, AA v 387.3-9, my italics)

The antinomy (2) appears between two constitutive objective principles that the determining power of judgment applies as higher order laws when it tries to unify the dissimilarities of the empirical laws of nature:

Thesis $\mathrm{c}$ : "All generation of material things is possible in accordance with merely mechanical laws».

Antithesis $_{\mathrm{c}}$ : «Some generation of such things is not possible in accordance with merely mechanical laws».

(KU, AA v 387.13-16, my italics)

The antinomy (3) appears when the human power of judgment confuses objective constitutive principles of the determining power of judgment and subjective regulative maxims of the reflecting power of judgment:

All appearance of an antinomy between the maxims of that kind of explanation which is genuinely physical (mechanical) and that which is teleological (technical) therefore rests on confusing a fundamental principle of the reflecting with that of the determining power of judgment, and on confusing the autonomy of the former (which is valid merely subjectively for the use of our reason in regard to the particular laws of experience) with the heteronomy of the latter, which has to conform to the laws given by the understanding (whether general or particular).

( $K U, \mathrm{AA} v$ 389.20-27, first two italics are mine)

The confusion reading can take two forms. The antinomy appears (3a) between an objective constitutive principle of the determining power of judgment (the application of higher order mechanical natural laws) and a subjective regulative maxim of the reflecting power of judgment (the application of higher order teleological natural laws). Or, the antinomy ( $3 \mathrm{~b}$ ) appears when the power of judgment confuses two subjective regulative maxims of reflecting power of judgment with two objective constitutive principles of determining power of judgment that human beings apply when they try to unify the dissimilarities of the empirical laws of nature. Scholars tend to read $(3 b)$ rather than ( $3 a)$ into the passage at the end of $\S 71$.

Let us consider these four readings. (3b) It is implausible to say that the antinomy of the human power of judgment consists in confusing a pair of subjective regulative

\footnotetext{
${ }^{1}$ Unless otherwise indicated, English quotations will be from The Cambridge Edition of the Works of Immanuel Kant, ed. by P. Guyer, A. W. Wood, Cambridge, Cambridge University Press, 1992-.
} 
maxims of the reflecting power of judgment with a pair of objective constitutive principles of the determining power of judgment. The antinomy in this case would consist of the misguidance regarding the epistemic status of the natural laws that human beings apply when they judge organized beings: they use natural laws as constitutive objective principles even though they can only be used as regulative subjective maxims. Quarfood ${ }^{1}$ proposes a version this reading when he writes that human beings tend to slip from merely regulative, hypothetic into constitutive, ontological claims when they judge organized beings as mechanical and purposive beings. As a consequence, the boundaries between both types of laws become blurred. According to Quarfood, Kant is warning his readers to not confuse the epistemic status of two regulative with two constitutive laws.

There is one general and strong objection against this reading. If the confusion about the epistemic status of judgments would be the antinomy mentioned, then the resolution of the antinomy would consist in the detection of the misguidance of our judgment regarding the epistemic status of both kinds of natural laws. And this would implicitly justify one of the readings (1) or (2) as the relevant reading, since, as the analysis of readings (1) and (2) of the antinomy will make clear, there are internal antinomies within each of the readings (1) and (2), namely (1) a resolvable conflict within the pair of regulative maxims of the reflecting power of judgment and (2) an irresolvable conflict within the pair of objective principles of the determining power of judgment. The detection that we should not confuse regulative subjective maxims with constitutive objective principles is insufficient to resolve the existing conflict between the regulative maxims (1) or constitutive principles (2) Secondly, it would be strange if Kant continued to write seven further sections $(\$ \S 72-78)$ although the resolution of the antinomy was already clear at the end of $\S 71$, and that he would name $\S 71$ a 'preparation for the resolution' of the antinomy if it presents not only the preparation but also the resolution of the antinomy.

Reading (3a) is not a prominent one in the literature, even though some scholars wonder why the Kant of the "Dialectic» of the Critique of the Power of Judgment seems to interpret mechanical laws as subjective regulative maxims and not as objective constitutive principles, as one would have expected him to do based on his account of mechanical natural laws in the Critique of Pure Reason and in the Metaphysical Foundations of Natural Science. But if the conflict were that between a teleological natural law as a subjective regulative maxim of the reflecting and a mechanical natural law as an objective constitutive principle of the determining power of judgment it would not be clear why there is a conflict at all since both kinds of laws would not result from the same either regulative or constitutive use of either the reflecting or the determining power of judgment. This reading of the antinomy disregards Kant's emphatic claim that the antinomy appears between to necessary maxims of the reflecting power of judgment, and not between two different natural laws, one of them generated by the reflecting, the other by the determining power of judgment. Kant clearly states that the antinomy arises when the reflecting power of judgment chooses different maxims, one of them offered by the faculty of understanding, the other offered

\footnotetext{
1 The Antinomy of Teleological Judgment, pp. 160-208 and The Antinomy of Teleological Judgment: What It Is and How It Is Solved.
} 
by the faculty of reason. Thereby the reflecting power of judgment sets its own standards of reflection and is threatened by a conflict between those standards:

But as far as the particular laws that can only be made known to us by experience are concerned, there can be such great diversity and dissimilarity among them that the power of judgment itself must serve as a principle even in order merely to investigate the appearances of nature in accordance with a law $[\ldots]$. Now in th[is] case $[\ldots]$ the power of judgment can set out from two maxims in its reflection, one of which is provided to it by the mere understanding a priori, the other of which, however, is suggested by particular experiences that bring reason into play.

$(K U, A A v 386.21-34)$

Now I shall explain why it is implausible to say that Kant tries to resolve the antinomy (2) between objective constitutive principles. In this case, the antinomy would appear as a conflict within the determining power of judgment (and a conflict in nature on an ontological level). The function of the determining judgment is to think of the particular as contained under the universal. Once the power of judgment accomplishes a determining procedure it does not search for a universal, since the universal is already given by understanding or reason, and the faculty of judgment searches for relevant particulars, which can be determined by this universal. To put that differently: the faculty of determining judgment is heteronomous, since, as Kant says at the beginning of $\$ 69$, it is itself not «nomothetic»; it only subsumes the particular under laws or concepts that - as objective principles - are given by understanding or reason (KU, AA v 385.5-15, see $K U, A A v 179.19-24)$. For this reason, the determining power of judgment cannot be at odds with its own universal maxims. However, it is Kant's project in the critique of the teleological power of judgment to prevent the power of judgment from a conflict within its own principles.

But this is not even the antinomy between objective constitutive principles of the determining power of judgment as Kant presents it. For, Antithesis ${ }_{\mathrm{c}}$ only negates that some features of organized nature can be judged by the means of mechanical natural laws. It does not state explicitly which laws will be applied instead when the determining judgment cannot apply mechanical natural laws (e.g., it does not mention teleological natural laws). Kant claims in Thesis ${ }_{c}$ that «[a]ll generation of material things is possible in accordance with merely mechanical laws»; whereas in Antithesis ${ }_{c}$ he claims that «[s]ome generation of such things is not possible in accordance with merely mechanical laws» (KU, AA v 387.13-16). The conflict is that the same principle of understanding is affirmed and partly negated. The resulting constellation of claims entails a logical contradiction, and thus, an antinomy that cannot be resolved. One of the claims must be false. ${ }^{1}$ This antinomy cannot be the target of Kant's «Dialectic».

\footnotetext{
1 All antinomies in the first and second Critiques are apparent antinomies: either they appear between two propositions, which both are false and invalid (see the propositions of the first and the second antinomy in the first Critique), or between two propositions, which both are true and valid (see the third and the fourth antinomy of theoretical reason in the first Critique and the propositions of the antinomy of practical reason in the second Critique). In the first case the resolution of the apparent antinomy consists in a third proposition which combines both true propositions. In the second case the resolution of the apparent antinomy consists in a proposition which claims an alternative third between both false propositions. Kant never tries to resolve an antinomy between a false and a true proposition since this is no antinomial conflict which can be resolved: the true proposition is true and valid. The false proposition is wrong and invalid.
} 
Another problem is that given the fact that Thesis $_{\mathrm{c}}$ states the universal validity of mechanical laws of understanding, and Antithesis ${ }_{c}$ neglects the universal validity of these laws of understanding (KU, AA v 387.13-16), both as objective constitutive principles of the determining power of judgment, one might wonder why Kant says about this antinomy that it is a conflict «not of the power of judgment, but rather a conflict in the legislation of reason» (KU, AA v 387.20-21). Why is this antinomy "a conflict in the legislation of reason" (my italics) and not in the legislation of understanding employed by the determining power of judgment? One way to justify this is to say that a positive consequence of the Antithesis is that human beings would either apply another concept of understanding or a concept of reason when mechanical laws do not suffice to explain organized beings according to mechanical natural laws. The term 'reason' would then designate reason in a wider sense, i.e., the totality of the faculties of our mind including understanding and reason in a narrow sense (the faculty of ideas).

However we reconstruct the conflict (2), it is such that it cannot be resolved. The determining power of judgment can follow either one or the other principle. Thus the resolution of the antinomy would be either that there is no antinomy at all (for we can follow only one of both principles), or that the antinomy is not resolvable in the sense that both principles are justified and that we have to find a way to combine and use them together, or that both principles are not justified and we have to find an alternative third. For this reason, the whole project of the «Dialectic», namely to detect threatening antinomies and to resolve them, would make no sense.

The most plausible among the four readings is (1) Kant tries to resolve an apparent antinomy between subjective regulative maxims of the reflecting power of judgment. This version of the antinomy suggests that there could arise an antinomy when our capacity of reflecting judgment searches for universal concepts under which it can subsume the manifold of particular empirical laws (or empirical characteristics of organized nature given in experience). In this situation, the reflecting power of judgment could either bring into play a universal concept offered by the faculty of understanding (a mechanical natural law, a model of efficient causation). Or, the reflecting power of judgment could make use of a universal concept offered by the faculty of reason (a teleological natural law, a model of final causation). In the first case - based on a universal concept of understanding - the reflecting power of judgment claims in Thesis ${ }_{\mathrm{r}}$ that all generation of material things and their forms must be judged as possible in accordance with merely mechanical natural laws. In the second case - based on a universal concept of reason (the idea of a purpose) - the reflecting power of judgment claims in Antithesis that some products of material nature cannot be judged as possible according to merely mechanical natural laws. Judging them requires a different law of causality, namely that of final causes. In each case, the reflecting power of judgment uses mechanical laws (a higher order concept offered by the faculty of understanding) and teleological laws (a higher order concept offered by the faculty of reason) as subjective regulative maxims for its reflection on the manifold empirical laws of nature. For this reason, the two higher order laws that the reflecting power of judgment brings into play as subjective maxims can provoke a conflict for the power of judgment when it tries to give itself a universal maxim for the reflection. I claim that exactly this conflict (1) is the antinomy mentioned. Let me fin- 
ish this discussion with a summary of the strongest reasons that speak in favor of reading (1):

First, the reflecting power of judgment is a faculty of the human mind that searches the unifying universal for the (empirically) given particular (see KU, AA v 179.2426). It is an 'autonomous' ( $K U, A A \vee 389.23$ ) capacity since it freely selects its own universals as subjective maxims which serve as a universal standard for its reflection. It is important to note that the reflecting power of judgment is not autonomous in the sense that it generates its own universals. It only selects universals, which are offered by understanding and reason (KU, AA v 386.28-34). By this selection, both universals change their status since now they are subjectively selected universal maxims within a reflexive process of the power of judgment. ${ }^{1}$ Thus, the reflecting power of judgment can indeed be at odds with its own choice of maxims if it selects two contradictory maxims as universals. ${ }^{2}$

Second, Kant explicitly says the reflecting power of judgment necessarily selects maxims for its reflection, which cause an apparent "conflict, hence an antinomy» or "natural dialectic». This conflict is an «unavoidable illusion»; however, it can be resolved by means of the critical method (KU, AA v 385.27-386.10). For the reflecting power of judgment Kant explicitly claims both: that there is an apparent antinomy within the power of judgment and that there is a resolution for the antinomy, which is made possible by the critical method.

And third, Kant states in the opening $\S 69$ of the «Dialectic» that the reflecting (and only the reflecting) power of judgment entails an apparent and a resolvable antinomy. In the immediately following $\oint 70$ he announces the representation of «this antinomy» (KU, AA v 386.12, my italics) in the heading. In the heading of $\S 71$ he advertises a preparation for the resolution of the "above antinomy» (KU, AA v 388.21, my italics). The deictic terms 'this' and 'above' indicate that the antinomy mentioned has already been introduced. In the heading of $\S 70$ 'this antinomy' unambiguously relates back to the antinomy between the subjective regulative maxims of the reflecting power of judgment mentioned in $\S 69$, for Kant did not introduce any other antinomy up to this point. In $\S 71$, then, for reasons of consistency, it is more plausible to say that the referent of the 'above antinomy' is the antinomy between the subjective regulative maxims of the reflecting power of judgment (KU, AA v 387.20).

\section{The Resolution of the Antinomy}

I now present what I consider to be possible solutions of the antinomy. It is Kant's strategy to argue for a supersensible ground of the unity of both kinds of natural laws, which justifies the unification of both kinds of natural laws in our human power of judgment. Two questions require special attention: how does Kant describe the supersensible ground that represents the unity of both kinds of natural laws? And to what extent does this offer a helpful explanation for the unification of both kinds of natural laws in our human power of judgment? In addition, the resolution of the an-

\footnotetext{
${ }^{1}$ Here I agree with P. McLaughlin, Kant's Critique of Teleology in Biological Explanation, pp. 133-134.

2 This reading of the antinomy has been suggested in Hegel's Wissenschaft der Logik (Georg Friedrich Wilhelm Hegel Werke, ed. by E. Moldenhauer, K. M. Michel, Frankfurt a.M., Suhrkamp, 1969, vol. 6, pp. 442-443).
} 
tinomy should be in harmony with the result stated above that the antinomy appears between two subjective regulative maxims of the reflecting power of judgment.

\subsection{The Idea of a Divine Artisan: "God» ( $\$ \oint 74-75, \oint 85$, and $\S 91)$}

The first notion that Kant presents as a resolution for the antinomy at the end of $\S 74$ and in $\S 75$ is the subjective regulative idea of a divine artisan, «a God» (KU, AA v 399.37400.6). In $\$ \S 74-75$ the resolution of the antinomy by the idea of a divine artisan is to some extent hidden behind other systematic aims that Kant follows in that section. ${ }^{1}$ But at the end of the third Critique, especially in his discussion of the physico-theological proof of the existence of God in $\S 85$ and $\S 91$, Kant gives more space to developing the idea of an artisan-like God as an instance that represents the unity of mechanical and teleological natural laws. There, ${ }^{2}$ Kant treats a similar notion of the subjective regulative idea of a divine artisan as in $\S 74$ and $\S 75$, and claims that the unity of both kinds of natural laws can be found in this notion of God. One of the aims of this paper is to emphasize the importance of the notion of the divine artisan for the resolution of the antinomy (against an overemphasis of the intuitive understanding), since then the discussion of the unification of the two kinds of laws of nature in the «Dialectic» has a better fit with Kant's view of the unity of the critical system in general, which he develops at the end of the third Critique.

What kind of regulative idea of a divine artisan does Kant have in mind? In $\$ \S 74-$ 75 he describes it in terms of a monotheistic (and not just a deistic) idea of a divine being. It is a "supreme» or "highest» (KU, AA v 399.12, 16), singular «being» (KU, AA v 397.16; KU, AA v 398.2; KU, AA v 399.3, 7; KU, AA v 400.29, 35). Kant explicitly speaks of one 'being' but not of a plurality of divine 'beings'. It is an extramundane "God» (KU, AA v 399.37; KU, AA v 400.5) that "exists outside of the world» (KU, AA v 399.23). ${ }^{3}$ This divine being is endowed with two kinds of facilities: epistemic facilities like intelligence ( $K U, \mathrm{AA} v$ 399.7, 13; KU, AA v 400.5), understanding ( $K U, \mathrm{AA} v$ 399.2-3), and intentionality ( $K U, A A v$ 398.31; KU, AA v 399.15-16, 21-22); and causal capacities like agency, potency, and productivity (KU, AA v 398.3; KU, AA v 399.11-12; KU, AA v 400.5). As an intentionally acting being, it is thought to be "a world-cause [Welturheber]» and "author [Urheber]» of the world (KU, AA v 400.30), which causes things in the world as "products of divine art [Producte göttlicher Kunst]" (KU, AA v 397.23).

If we compare these statements in $\$ \oint 74-75$ with Kant's claims about the divine artisan in $\oint 85$ and the appendix to $\S 91$, it is striking how much the physico-theological idea of God, which Kant discusses in the final sections of the third Critique, corresponds to the idea of a divine artisan in $\S \S 74-75$. In $\S 85$ and $\S 91$ Kant characterizes «the highest artist [höchsten Künstler()]» (KU, AA v 438.5-6) as a "highest world-cause [oberste Weltursache]» (KU, AA v 439.19; KU, AA v 476.24) and "world-author [Welturhe-

\footnotetext{
1 On the surface of $\S \S 74-75$ Kant demonstrates that dogmatic treatments of nature's teleology fail. Kant claims that teleological judgments just have a regulative and not a constitutive status.

2 Especially, I have sections KU, AA v 476.17-480.36 from the "General Remark on the Teleology", the appendix of $\S 91$, in mind, where Kant gives another detailed discussion of the physico-theological argument and its restricted function within the critical system.

${ }^{3}$ Implicitly, Kant rules out that the unity of both kinds of natural laws could rely on the idea of a worldimmanent pantheistic or Spinozistic divinity or on polytheistic divinities. The divine ens extramundanum might also be a personal anthropomorphic God, but Kant is not explicit on that point.
} 
ber]» (KU, AA v 438.3; KU, AA v 439.18), which functions as an "original ground of nature [Urgrund() der Natur]》 (KU, AA v 476.22). As a "highest understanding [höchste( $r$ ) Verstand()]» (KU, AA v 476.24) it is an intelligent ( $K U, \mathrm{AA} v 438.6,19 ; \mathrm{KU}, \mathrm{AA} v$ 440.22) and intentional being ( $K U, \mathrm{AA} \mathrm{v}$ 440.32).

The physicotheological idea of a divine artisan presupposes an analogy between the divine and human beings: God, Kant writes, «is productive in accordance with the analogy with the causality of an understanding” (KU, AA v 398.2-3). Roughly, this analogy is that of two craftsmen and their products: like a human watchmaker produces a watch, the divine master craftsman creates the world. However, Kant is not explicit with regard to the coverage of the analogy between human and divine understanding and causation. With regard to the faculty of human and divine understanding in $\S \S 74-75$, he leaves open whether the analogy consists in the claim that both beings have a faculty of understanding, which is similar or in the claim that both beings have a faculty of understanding, which is not similar. With regard to the analogy between human and divine productivity, he leaves open whether the divine artisan has a free will or emanates the world. In addition Kant does not say clearly whether the divine artisan creates only the form of the world, whereas matter exists eternally, or whether he is the creator of form and matter also. Let us consider these characteristics of the divine artisan in closer detail.

In view of an account of a divine artisan's understanding both readings of the analogy mentioned would require different foundational scenarios on a supersensible level. The first scenario would show us a divine artisan whose understanding is similar to, if not even partly identical with the human understanding and who endows nature with characteristics (among others) that correspond to the mechanical and teleological natural laws, and their order in the divine artisan's consciousness. Consequently, corresponding to the laws in the divine artisan's understanding, nature would entail mechanical and teleological orders and their hierarchy.

This reading offers a straightforward explanation of the extent to which the divine understanding on the supersensible level would be the ground for distinctions in our understanding - since our and the divine artisan's understanding and the resulting experience of nature would in part entail identical orders: the divine artisan's understanding would just be more complete and inclusive than our human understanding. In this scenario the unification of both kinds of natural laws and the corresponding orders of nature would follow a pattern of artificial production: an artist uses matter (which can be described by mechanical natural laws) as a means to actualize his idea of an artificial object as an end or purpose (which can be described by teleological natural laws). - However, a problematic feature of this reading is that the conception of the divine artisan's understanding comes too close to the conception of the human understanding, and for this reason, also too close to what Kant describes as the conceptual limitations of the human understanding in $\$ \S 76-77$. And how can we imagine a divine understanding, which is limited as ours? For this reason, a more restricted analogy between the divine and the human understanding seems more plausible - and, as I will claim in the following section (3.2), such a restricted analogy would match an intuitive understanding.

Let us look now at the second capacity. What does Kant mean when he says that in the idea of a divine artisan we consider God a "world-cause» and an «author» (KU, 
AA v 400.30) of the world? Whereas the Critique of the Power of Judgment provides no real explanation of either term, the lecture notes on rational and natural theology from the 1780 s suggest specific meanings of these terms. In these notes Kant distinguishes between a world-cause (Weltursache), as part of a deistic notion of God; an author of the world (Welturheber) as part of a theistic notion of God in natural theology (physicotheology and cosmotheology); and a regent of the world (Weltbeherrscher), as part of a theistic notion of God in moral theology (V-Phil-Th/Pölitz, AA xxviı/ / 2.2 1091.22-1097.18). An author of the world is a living God whose free will, understanding, and supreme intelligence are the causes of everything in the world (V-PhilTh/Pölitz, AA xxviII/2 1047.24-27). An author of the world could either be an architect of the form of the things only or a creator of «the matter of the substances in the world» (V-Phil-Th/Pölitz, AA xxviII/2.2 1093.17-21). Supposing that Kant did not change his mind between the early 1780 s and Critique of the Power of Judgment in 1790, we can cautiously assume that the notions of a world-cause and author of the world imply a divine artisan who causes the world based on his intelligence and his free will. It cannot be clarified on the basis of the Critique of the Power of Judgment and the lecture notes whether this divine artisan is an architect of the form or a creator of form and matter of the world. But it should be mentioned that in his lectures Kant argues against the view that God could be merely an architect of the forms of the world. He defends the view that God is the creator of the forms and the substances of all material things in the world, since only then - and this argument is also decisive for the function of the idea of a divine artisan in the Critique of the Power of Judgment - is matter also subordinated to God's will. Otherwise nature would become a second principle beside and as strong as God, following its own, independent laws (V-PhilTh/Pölitz, AA xxviII/2.2 1094.5-1098.25; V-Th/Volckmann, AA xVIII/2.2 1196.161197.20). The argument from the lectures supports a reading of God's causality in the Critique of the Power of Judgment as a creation of form and matter also, since only then the subordination of the laws of matter under the laws of its form could be granted - and this thought is required for the resolution of the antinomy. ${ }^{1}$

Against this suggestion, it could, first, be objected that Kant refers to an «architect» in $\S 78$ (KU, AA v 410.20), and to an "architectonic understanding» in $\S 71$ (KU, AA v 388.35) and $\S 80$ (KU, AA v 420.23-24, see also KU, AA v 438.3 in $\S 85)$, which could suggest that he is a creator of the form of the world only. However, it is not entirely clear whether these passages describe Kant's own position. It could, secondly, be objected that in $\$ \S 74-75$ Kant seems at first glance to emphasize the responsibility of the idea of God for the purposive form of organized beings only, which means for the finalistic order in the world that lead human beings to an application of the teleological natural laws. God's intentional actions and intelligent productions, he claims, serve as an explanation for the purposive, intentional characteristics of organized nature, which human beings judge to be teleologically organized. ${ }^{2}$ Kant does not say much about

\footnotetext{
1 A similar view of God as a creator of both, the matter and the form of the world, can be found in Kant's early Argument essay, even though in the Argument essay Kant still tries to prove a dogmatic concept of a divine creator which is no longer true in the Critique of the Power of Judgment (where he argues that the divine creator of the matter and form of the world is a regulative idea).

2 At this point I would like to remark that Kant explicitly designates the idea of God as an «indispensably necessary maxim» (KU, AA v 400.7; KU, AA v 398.10-31, my italics) that reason prescribes to the reflective pow-
} 
the idea of a divine artisan as a thinker of the mechanical laws and a creator of mechanical properties of nature. However, some passages suggest that the divine artisan is the creator in a richer sense that includes the creation of the mechanical properties of nature. For instance Kant claims that we "cannot conceive of the purposiveness [...] of many things in nature and make it comprehensible except by representing them and the world in general as a product of an intelligent cause (a God)" (KU, AA v 400.1-6, my italics). In $\S 85$ and $\S 91$ Kant similarly insists that the divine artisan is responsible for the unity of all theoretical laws within the realm of nature. It is a "concept of the original being» that creates the realm of nature according to the laws of its intelligence and understanding, and which offers the grounding for "the whole cognition of nature» (KU, AA v 476.32-33, my italics) for human beings. ${ }^{1}$

Let us look back. So far I have argued that the first scenario, which Kant offers as a resolution of the antinomy describes the idea of a divine artisan that unifies the two kinds of natural laws on a supersensible level. The characteristics of this artisan are a specific kind of understanding and causation. Whereas it is implausible to say that the divine artisan's understanding is directly analogous or even partly identical with a human understanding, an alternative constitution of God's understanding is still outstanding. God's causal activity (on the basis of his arguments in the lecture notes) rather turns out the be a generation of form and matter also, since only then matter and mechanism could be subordinated to the form and teleology of nature. ${ }^{2}$

er of judgment (that is he uses exactly the same vocabulary, namely 'maxim', which he uses in the introduction of the antinomy of reflecting judgment). This maxim helps us to consider nature as ordered and generated with intention (KU, AA v 398.29-31).

${ }^{1}$ Most passages of Kant's account in $\S \S 74-75, \S 85$ and $\S 91$ can be read as part of a physico-theological notion of God, i.e., as part of a description of the efficiency of a divine artisan (very explicit see: "products of divine art»: KU, AA v 397.23; "an artistic intelligence»: $K U, \mathrm{AA} v$ 441.3; "an intelligent world-cause (as the highest artist)»: $K U, A A v$ 438.6-7). However, a few passages do not fit into this picture: even though they can be interpreted as part of a notion of God which - as the physico-theological notion of God - belong to natural theology, they do rather resemble the cosmological and not the physico-theological argument. I have, for example, passage KU, AA v 398.32-399.5 in mind, where Kant seems to claim that the "contingency" which we experience when we judge single organized beings or the organized nature as a whole leads us to the presupposition of one necessary being, namely God. The inference of the contingency in the world ("a contingentia mundi») from a necessary being is the basis of the cosmological proof of the existence of God (see, e.g., $\mathrm{KrV}, \mathrm{B} 632-634$; $\mathrm{KrV}, \mathrm{B}$ 643-648).

${ }^{2}$ I would like to give an additional argument for the claim that idea of a divine artisan is a resolution of the antinomy (or as I will argue more precisely in the following: is a part of the resolution of the antinomy). A whole line of interpreters of the antinomy - F. Delekat, Immanuel Kant, Heidelberg, Quelle \& Meyer, 1969, p. 463; R. Löw, Die Philosophie des Lebendigen, Frankfurt a.M., Suhrkamp, 1980, pp. 206-208, and in our days Frank-Zanetti (Dialektik der teleologischen Urteilskraft, pp. 1292-1294) - claim that there are two temporal distinct levels of text within the $\S \S$ of the antinomy: a younger (later written) level in $\S \S 69-75$, and an older (earlier written) level in $\$ \S 76-78$. If we take 'later written' in the sense that Kant partly revised his earlier version and legalized a new line of thought, then we receive much support for the claim that the notion of the divine artisan must be considered a decisive part of the resolution of the antinomy: since according to this interpretation Kant's later written version of the antinomy begins with the presentation of the antinomy in $\$ \S 69-71$, continues with Kant's rejection of dogmatic treatments of teleological maxims in $\S \S 72-73$; whereby Kant claims at the end of $\S 73$ that although dogmatic theism has to be rejected it offers the most compelling account among the criticized dogmatic accounts of teleology (KU, AA v 395.3-8). In $\S \S$ 74-75 Kant continues to discuss the theistic account and modifies the objective constitutive validity of the idea of a divine artisan, which belongs to an account of dogmatic theism, to a subjective regulative one. Beside this modification he describes the subjective regulative idea of a divine architect as a world-cause and author of the world in general. In these interpretations the notion of a divine artisan would be the end of 


\section{2. The Idea of an Intuitive Understanding ( $\$ \oint 76-77)$}

A second notion that Kant uses to present the resolution of the antinomy is the idea of an intuitive understanding. Whereas in $\S \S 74-75, \S 85$ and $\S 91$ Kant discusses the notion of a supersensible divine artisan, the notion of an intuitive understanding that he mentions in $\S \S 76-77$ is a narrower account, since it covers the divine consciousness only. Many contemporary interpreters consider the notion of the intuitive understanding the resolution of the antinomy. ${ }^{1}$ It consists, first, in the proof that the problematic distinction between higher order mechanical and teleological natural laws, and the corresponding characteristics of nature exist in our discursive understanding only and in our human experience of nature - in nature as it appears to us, but not in an alternative intuitive understanding, which is distinct from ours, and not in nature as such. Second, the intuitive understanding nonetheless is the supersensible ground for our human experience of organized nature.

The central claim of this account of the resolution is that the conflict between the two kinds of higher order natural laws disappears from a different (divine) point of view, which is not the human one, and by an access to nature as it is represented in this understanding, which human beings do not have. The antinomy is caused by a peculiarity of our human understanding and its restricted discursive use. It arises only with regard to organized nature as it appears to us; both the intuitive understanding as a supersensible ground and nature as it is experienced in this ground are free of the antinomial laws. For this reason, the notion of an intuitive understanding harmonizes with the previous result that, for Kant, the antinomy arises between subjective regulative maxims of the reflecting power of judgment only and not between objective constitutive principles of the determining power of judgment. However, precisely because the idea of an intuitive understanding is not analogous to our understanding, a major difficulty of this scenario is to explain how the intuitive understanding and its experience of nature is a supersensible ground for our human understanding, for nature as it appears to us, and for our way to resolve the antinomy which is a problem only for the human power judgment (see 3.5).

The notion of an intuitive understanding is extremely rare in Kant's published writings. It appears in $\S \S 76$ and 77 in the Critique of the Power of Judgment, and there is one mentioning of the term in the Critique of Pure Reason, B 723-724. However, several illuminating passages can be found in Kant's lectures on logic around 1771, in his lectures on rational and natural theology around $1783 / 1784$, and in his lectures on meta-

the discussion of the antinomy (!). Given that this is the later (and therefore more legalized) version of the antinomy, then the idea of a divine artisan must be a key for the unification of the two kinds of laws of nature, since Kant poses this idea beside earlier ones (the intuitive understanding, the underdetermined supernatural ground of nature), which suggests that the divine artisan does not contradict (maybe includes) the other two notions.

${ }^{1}$ Most prominently Förster (Die Bedeutung von $\$ \oint 76,77$ der Kritik der Urteilskraft, Teile I-II; Von der Eigentümlichkeit unseres Verstandes; Die 25 Jahre der Philosophie, pp. 147-160, 253-276); Frank-Zanetti (Dialektik der teleologischen Urteilskraft, pp. 1292-1303) and Quarfood (The Antinomy of Teleological Judgment, pp. 160-208 and The Antinomy of Teleological Judgment: What It Is and How It Is Solved). For a contrary reading of the resolution of the antinomy without reference to the intuitive understanding, see A. Breitenbach, Die Analogie von Vernunft und Natur, pp. 129-131. 
physics around $1790 / 1791 .{ }^{1}$ In addition, two reflections (Refl 6041, AA XVIII 431.16-27 and Refl 6048, AA XVIII 433.15-434.3) from 1780/1789 directly address the notion of an intuitive understanding. I will include these passages at some points to clarify Kant's account of the intuitive understanding in the Critique of the Power of Judgment, since they provide a consistent view that covers a period of more than twenty years (from the 1770 s until the beginning of the 1790s). Most of these notes stem from the 1780 s the time of the development of Kant's account in the Critique of the Power of Judgment.

In $\S \S 76-77$ of the Critique of the Power of Judgment, Kant presents the intuitive understanding as the idea of an understanding, which is "higher» (KU, AA v 406.2) than our understanding. McLaughlin ${ }^{2}$ pointed out that this statement in the Critique of the Power of Judgment does not necessarily mean that the intuitive understanding is an infinite and divine one, since it could be higher than our understanding, but still finite. Based on an immanent reading of the Critique of the Power of Judgment only, this interpretation is possible, since Kant nowhere in the Critique of the Power of Judgment explicitly characterizes the intuitive understanding as a divine and infinite understanding. However, in his lectures, notes, and fragments (which are our most important indirect source to elucidate Kant's thoughts) Kant consistently identifies the intuitive with a divine understanding. And it is worthy of note that Kant ascribes this kind of understanding even to different notions of deistic or theistic divine entities, ${ }^{3}$ suggesting that this understanding is the specific understanding of whatever kind of divine entity (i.e., a physicotheological, cosmotheological, ontotheological, ethicotheological notion of God - which allows us to ascribe this understanding to the divine artisan, see 3.4). In a similar vein, Kant writes: «It is hard to see how any intuitive understanding besides the divine one could take place» (AA xvIII 433.16-17, my transl.). I am inclined to think that this is Kant's view also in 1790: the intuitive understanding is part of the idea of a divine (an therefore infinite and unlimited) understanding. ${ }^{4}$

The intuitive understanding, Kant claims, is "a faculty of a complete spontaneity of intuition» (KU, AA v 406.21-22); it is "archetypical [urbildlich]» (KU, AA v 408.19; KU, AA

\footnotetext{
${ }^{1}$ See, e.g., V-Phil-Th/Pölitz, AA xxvin//2.2 1051-1053; V-Phil-Th/Pölitz, AA xxvin//2.2 1114-1115; V-Th/Volckmann, AA xxvIII/2.2 1158.20; V-Th/Volckmann, AA xxvIII/2.2 1165.25; V-Th/Volckmann, xxviII/2.2 1214.33; V-Th/Baumbach, AA xxviII/2.2:1254; V-Th/Baumbach, AA xxvIII/2.2 1266-1269, and V-Met-L2/Pölitz, AA xxviII / 2.1606.

${ }^{2}$ P. McLaughlin, Kant's Critique of Teleology in Biological Explanation, pp. 170-171; Mechanical Explanation in the "Critique of the Teleological Power of Judgment".

${ }^{3}$ See, e.g., ontotheology: V-Phil-Th/Pölitz, AA xxvıı / 2.2 1017; cosmotheology: V-Phil-Th/Pölitz, AA xxvıII / 2.2 1051-1053; physicotheology: V-Phil-Th/Pölitz, AA xxvin//2.2 1065; ethicotheology: V-Phil-Th/Pölitz, AA XXVIII/ 2.2 1114-1115; various: V-Th/Volckmann, AA xxviII/2.2 1139, 1158, 1214; ontotheology: V-Th/Baumbach, AA XXVIII/ 2.2 1254; V-Th/Baumbach, AA xxVIII/ 2.2 1266-1269.

${ }^{4}$ McLaughlin is led to his interpretation by an immanent reading, and, from this perspective, he is right to insist that Kant nowhere mentions the divinity of the intuitive understanding; and an interpretation, which reads the intuitive understanding as a finite understanding, i.e., an understanding, which is not divine, is justified. Förster (Von der Eigentümlichkeit unseres Verstandes, p. 273), in contrast, reads Kant's notion of an intuitive understanding based on the lectures, notes, and fragments (which stem from the same years), where the intuitive understanding is overwhelmingly clear identified as a divine understanding. Although Förster is not right to say that Kant characterizes the intuitive understanding as a divine understanding in the Critique of the Power of Judgment, since this claim only appears in the lectures, I agree with him systematically that this is Kant's position also in the Critique of the Power of Judgment. Förster also mentions the possibility of a finite, intuitive understanding, and claims that Kant was aware of it, but presupposes the exclusion of this reading, even though Kant does not justify it (see KU, AA v 409.34-35).
} 
$\mathrm{V}$ 407.32). In contrast, our human understanding is a faculty of the spontaneity of concepts and principles (laws) of understanding. It is «discursive» (KU, AA v 406.25) and «ectypical [nachbildend]», which means «image-dependent» (KU, AA v 408.21). What does this comparison mean? In the Critique of Pure Reason, and from a different perspective in his lectures on rational and natural theology, Kant explains at several places that our human understanding is restricted in a twofold sense. The first restriction is caused by the faculty of sensibility: our understanding cognizes objects only by universal features which it obtains by attention and reflection on, by comparison of and by abstraction from objects given in experience that affect the faculty of sensibility (see V-Phil-Th/Pölitz, AA xxviII/2.2 1052-1053). Our understanding is ectypical or image-dependent in the sense that it gains sensible intuitions passively only by the influence of objects of experience on the subject. The faculty of reason causes another restriction. Reason avoids the maximal extension of our understanding on problematic concepts (ideas, originaria, Urbilder), which are unconditioned by sensible intuitions (V-Phil-Th/Pölitz, AA xxviı / 2.2 1053.7-10). It avoids the invention of new concepts that are not abstracted by understanding from objects of experience but inferred by reason from other concepts of understanding. Thus, reason constrains the maximal extension of understanding to the cognition of objects for which the faculty of sensibility can provide the materials and represent them in our intuition (see $V$ Phil-Th/Pölitz, AA xxviII/2.2 1052, and also KrV, B xIX-Xxxi). Our understanding, therefore, is cut off from an immediate access to sensible intuitions provided by the faculty of sensibility and from an immediate access to unconditioned concepts (ideas) withheld by the faculty of reason.

An intuitive understanding is neither restricted by the senses nor by reason; ${ }^{1}$ it is an unlimited understanding in its maximum extension ("understanding in the most general sense of the term»: KU, AA v 406.23-24), since it has an immediate maximal access to what would be intuitions for our faculty of sensibility, concepts for our faculty of understanding, and ideas for our faculty of reason. It follows that for an intuitive understanding what would be distinct kinds of representation (intuitions, concepts, ideas) for us is intuitively given in the "complete spontaneity of intuition» (KU, AA $\mathrm{v}$ 406.21-22). The distinction between mechanical natural laws (relying on intuitions and concepts of understanding) and teleological natural laws (relying on intuitions, concepts of understanding, and ideas of reason that cannot be given in intuition) and their antinomy disappears, since for such an understanding the representation of the contents of both laws would be given as intuitions.

Further, the intuitive understanding is characterized such that it "goes from the synthetically universal (of the intuition of a whole as such) to the particular, i.e., from the whole to the parts» (KU, AA v 407.21-23). ${ }^{2}$ The intuitive understanding spontaneously

\footnotetext{
1 This point clarifies why Kant calls the intuitive understanding an 'understanding', and not 'reason', although the coverage of this understanding is equivalent to ideas. Reason, for Kant, is a limiting faculty only, which serves to give understanding its empirically verifiable concepts and, thus, its borders.

2 A subordinate problem at this point is whether an intuitive understanding, which, as Kant claims, is "not discursive», and is a faculty of a "complete spontaneity of intuition» instead, has concepts and discursive laws at all. Does Kant's claim mean that the intuitive understanding has no concepts of whatever kind (and therefore no discursive laws, but perhaps a different kind of laws), or does it just mean that it has concepts, but they are different from ours (and therefore does have laws, which are expressed by a different kind of concepts, or even
} 
generates a whole of intuitions, which, as Kant claims, is similar to the «unity of space» in that "in it no part can be determined except in relation to the whole (the representation of which is thus) the basis of the possibility of the parts» (KU, AA v 409.38). Kant does not say much about the comparison to the unity of space in the Critique of the Power of Judgment. But if we return to the relevant passages in the Critique of Pure Reason, we can find the following characteristic:

Space is not a discursive [...] but a pure intuition. For, first, one can only represent a single space, and if one speaks of many spaces, one understands by that only parts of one and the same unique space. And these parts cannot as it were precede the single all-encompassing space as its components (from which its composition would be possible), but rather are only thought in it. It is essentially single; the manifold in it [...] rests merely on limitations. [...] Space is represented as an infinite given magnitude. [...] [It is one] representation that [...] can be thought as if it contained an infinite set of representations within itself. [...] [A]ll the parts of space, even to infinity, are simultaneous.

$(\mathrm{KrV}, \mathrm{B} 39-40)$

The comparison to the unity of space suggests that the intuitive understanding is an intuited single whole, which precedes and entails intuited parts, i.e., more limited intuitions. Since more limited intuitions can be spelled out only with regard to the preceding intuited whole (as a diminishment of the whole), and the intuited whole in turn consists in the intuited parts within the whole, it cannot be said that some parts of the whole are more or less necessary or contingent (which causes the antinomy for our understanding), since of all them constitute the whole and the relationships within the whole. An intuitive understanding is a representation of a whole in which "there is no contingency in the combination of the parts, in order to make possible a determinate form of the whole» (KU, AA v 407.23-25). Nevertheless such an understanding has endlessly many possibilities to represent non-discursive, law-like orders, hierarchies, and relationships within an intuited whole; since it can represent infinitely many law-like structures intuitively in the form of part-whole-relationships.

In contrast, for our understanding «a real whole of nature is to be regarded only as the effect of the concurrent moving forces of the parts" (KU, AA v 407.28-30, my italics). For our human understanding a whole is always the result of the composition of parts, it is never prior to the parts, and therefore it is not a real whole but just an aggregate of parts. What exactly does this mean? If our understanding tries to think a whole it «must progress from the parts, as universally conceived grounds, to the different possible forms, as consequences, that can be subsumed under it». For this reason, our understanding entails a "contingency in the combination of the parts, in order to make possible a determinate form of the whole» (KU, AA v 407.24-28). If our understanding tries to compose a whole, it must either begin with real parts, and has to add other real parts to compose a real aggregate. Or it has to borrow the possibility of a whole from an idea of reason, however, then, this whole is not real, but just

by intuitions)? Since Kant never mentions an alternative kind of concepts, I am inclined to say that, according to Kant, the intuitive understanding spontaneously produces intuitions only, and has no discursive concepts at all. However, this does not rule out alternative ways to express law-like structures. This might be the reason why Kant reformulates the problem of the antinomy in form of an antinomy - not between two kinds of laws - but two kinds of part-whole-relationships. 
the possibility of an idea of a whole. For this reason the only instance that can think of and generate a real whole is the intuitive understanding. It follows immediately that only an intuitive understanding can cognize the reality of an organized being (and the reality of a purpose or function of the organized being), whereas organized beings for us are not real but just possible, i.e., an idea of a purpose or function of an organized being.

We could ask, further, whether the intuitive understanding is or is not causally active, i.e., whether it is just an epistemic point of view - a theorizing divine consciousness - or a consciousness that acts upon the world. ${ }^{1}$ Kant does not say much about this point in $\S \S 76-77$ of the Critique of the Power of Judgment. In the final sentence of $\S$ 77 , however, he claims that teleological explanations must be grounded in an "original understanding as cause of the world [Weltursache]» (KU, AA v 410.11, my italics), which, of course, is a causal notion.

\subsection{The Idea of an Undetermined Supernatural Ground of Nature ( $(78)$}

I want briefly to consider a third notion - one, which Kant uses in $\S 78$ : the idea of a «supersensible» (KU, AA v 412.12, 35), «supersensible ground» (KU, AA v 413.14-15) or «supersensible substratum of nature» (KU, AA v 414.30). He characterizes this as an "undetermined concept of a ground [unbestimmten Begriffeines Grundes]» of nature, which we cannot determine "more precisely by any predicate» (KU, AA v 412.13-16). It is neither designated as a being like the divine artisan, nor as an understanding or consciousness like the intuitive understanding, but only as (a whatever kind of) supersensible ground of nature. Kant claims that from our human «theoretical point of view, we cannot form the least affirmative determinate concept of this» ground (KU, AA v 412.36-37, my italics); it can be «indicated but can never be determinately cognized» (KU, AA v 412.29). The supersensible is an extramundane ground, a "single higher principle» from which both kinds of laws of nature "flow» (KU, AA v 412.2425). Although distinct from mechanical and teleological laws, it entails the common root of both:

The principle which is to make possible the unifiability of both [kinds of laws] in the judging of nature in accordance with them must be placed in what lies outside of both (hence outside of the possible empirical representation of nature) but which still contains the ground of both, i.e., in the supersensible, and each of these two kinds of explanation must be related to that.

$$
(K U, \mathrm{AA} \text { v 412.8-13) }
$$

In this third notion Kant describes a supersensible ground of whatever kind, which is distinct from both kinds of laws, but from which both laws «flow [abfließen]» (KU, AA $\mathrm{V}$ 412.25). Doubtlessly «flow» suggests a causal notion in which the supersensible functions as the cause, and mechanism and teleology as the effects of this cause. I will not follow the term "flow» here as a trace to specify this causal notion. It could let us associate a divine instance that does not create the substances of the world by God's in-

\footnotetext{
${ }^{1}$ For a very demanding discussion of the causality of the intuitive understanding, which is, for systematic reasons, partly against the text of the Critique of the Power of Judgment, see E. FörsTER, Von der Eigentümlichkeit unseres Verstandes and Die 25 Jahre der Philosophie.
} 
tentional free will, so that both natural laws coexist in our consideration of nature, but emanates them (see for such an emanative causal notion of the world V-PhilTh/Pölitz, AA xxviII / 2.2 1092.9-17). But «flow» is a singular term not only in $\S 78$, but also in the whole third Critique and is rare in Kant's other writings, and mostly has just a physical meaning, connected to descriptions of fluids and mechanical descriptions of their motion. Only a few passages have a theological context (e.g., NTH, AA I 334.1314; BDG, AA II 118.17). I recommend taking this term as a general causal description which Kant does not want to specify any further at this point. The predominant feature of this notion is that it is the unifying supersensible root for our mechanical and teleological consideration of nature that "make[s] possible the unifiability of both in the judging of nature» (KU, AA v 412.8-9). In the following passages Kant does not explain how the unification of both laws is made possible on the basis of this ground but rather develops an argument, how they are unifiable for us. I will come back to this final thought in part 3.5.

Let us summarize. So far I demonstrated that Kant argues for a supersensible ground of the unity of both kinds of antinomial laws. I distinguished three notions that Kant seems to use when he talks about the resolution of the antinomy on a supersensible level: the idea of a divine artisan, the idea of an intuitive understanding, and the idea of an undetermined supernatural ground of nature. Two questions remain. The first is as to whether and if so, how the three notions relate to each other? The second: does Kant offer an argument to what extent the supersensible is a ground for the unification of both kinds of laws in our human judgment?

\section{4. The Divine Artisan, the Intuitive Understanding, and the Undetermined Supersensible Ground of Nature: Reconsidered}

Did Kant fail to develop a consistent idea of the supersensible? I would now like to discuss an exclusive, reductive, and an inclusive reading of the relationship of these three ideas. An advocate of an exclusive reading of these three notions could put into question whether the notion of the undetermined concept of a supersensible ground of nature in $\S 78$ matches both, the determinations of a divine artisan and the determinations of an intuitive understanding. In $\S \S 74-75$ we can find the description of an artisan-like divine being whose consciousness and causal properties lead it to the execution of creative actions. In $\S \S 76-77$ - even though most of the characteristics of the intuitive understanding are contrastive or negative - Kant presents a divine understanding that is positively characterized by its mode of intuitive part-whole-representations of all things, the move from the synthetic universal to the part through intuitions, the use of part-whole-relations as ordering structures instead of conceptual discursive laws, and by its causal force as the origin of the world. How can these determinations concur with the characterization of the supersensible as an undetermined ground? It is also true that a $\mathrm{KU}$-immanent reading of the intuitive understanding does not necessarily support an interpretation of this understanding as a divine one (as McLaughlin's view demonstrated), and if so, it could not be harmonized with the notion of a divine artisan's consciousness. Hence, the advocate of an exclusive reading would conclude that Kant failed to harmonize his views. But this would imply that Kant was blind against the oddities and misconceptions of his theory, which is unlikely. 
An alternative interpretation would be a reductive reading: there is a strong tendency in the literature to develop reductive interpretations of Kant's antinomy, for instance Breitenbach ${ }^{1}$ does not even mention the intuitive understanding in her interpretation and solely focuses on the hierarchy of laws as the resolution of the antinomy for us. McLaughlin ${ }^{2}$ develops a less radical reductive interpretation, which just diminishes the divine potential and infinite power of the intuitive understanding, but still considers the intuitive understanding part of the resolution of the antinomy. The advocate of a reductive reading could describe the narrative of $\$ \S 74-78$ such that Kant, step by step, frees the supersensible ground from properties which are irrelevant with regard to the notion of the requested supersensible unity: the traditional idea of a divine artisan $(\oint \S 74-75, \S 85$, and $\S 91)$ is a more comprehensive notion than the idea of an intuitive understanding $(\$ \S 76-77)$, and both of them are more determined concepts than the notion of an idea of an undetermined supersensible ground of nature $(\$ 78)$. This reading boils down to the idea of an undetermined supersensible ground of nature in $\S 78$ - which turns out to be a thin notion: a supersensible principle that we do not know and understand, a supersensible source of whatever kind that we only presuppose as a regulative principle to guarantee the divine unity and the unification of both kinds of laws of nature for us. - A major objection against this reading is that it cannot offer a plausible explanation as to why Kant returns to the physicotheological notion of God as a unifying supersensible instance of the laws of nature in $\S 85$. Why should Kant return to his richest and most inclusive notion of a supersensible if it were his basic interest to reduce the theological implications of the resolution of the anatomy as much as possible?

The proponent of an inclusive reading, which I would like to defend, could argue that the notions of a divine artisan, an intuitive understanding, and an undetermined supernatural ground of nature are aspects of one and the same rich idea of a supersensible: the intuitive understanding is exactly the consciousness of the divine artisan, which is effective as a supernatural ground of nature. This reading has strong support from Kant's lectures on rational theology where Kant identifies the intuitive understanding at many places with the consciousness of the physicotheological divine being. It refines a more anthropomorphic version of the traditional physicotheological notion of God since it does not straightforwardly claim that the limited human consciousness is part of God's consciousness, but ascribes to it an unlimited intuitive understanding instead, which is free of the discursive restrictions of the human understanding. All three notions describe an instance outside of the world. And all three notions are in harmony when we read them as causal interpretations of the supersensible (rather than just a theorizing epistemic point of view that does not act upon the world), since in all three notions causal descriptions are traceable: the divine artisan functions as cause and author of the world (KU, AA v 400.30), the intuitive understanding as world cause (KU, AA v 410.11), the supersensible ground as source of the outflow (KU, AA $\mathrm{v}$ 412.25) of the world. ${ }^{3}$

\footnotetext{
1 A. Breitenbach, Die Analogie von Vernunft und Natur.

2 P. McLaughlin, Kant's Critique of Teleology in Biological Explanation; Mechanical Explanation in the "Critique of the Teleological Power of Judgment».

3 This reading could be threatened by the inconsistency that in $\S 85$ Kant mentions the possibility that the divine artistry could also mean a group of designers. One could weaken this objection by saying that in this
} 
The advantage of the inclusive reading is that it allows us to connect the discussion of the unification of mechanical and teleological natural laws in $\S \S 74-78$ with Kant's considerations about the unity of the laws of nature in $\S 85$ and $\S 91$, in which he ascribes the unity of those natural laws to a physicotheological notion of God, i.e., the divine artisan. I think this is an important challenge of Förster's (and Frank-Zanetti's interpretations of $\S \S 76-77 .{ }^{1}$ Their readings focus solely on the intuitive understanding and do not connect it to the physiotheological notion of God, which is required for a consistent reading of Kant's discussions of the unity of the critical system at the end of the third Critique.

\subsection{A Supersensible Ground for Our Experience of Nature and the Hierarchy of Laws}

One might wonder to what extent the supersensible is a ground for our human judgment. If at all - how does the disappearance of the antinomial conflict on a supersensible level help us to resolve the conflict between two kinds of laws in our human judgment? And how do we resolve the conflict between the two kinds of laws?

At numerous places Kant addresses nature and the world in general explicitly as 'creation'. To mention a selection of these passages: in $\S 68$ Kant speaks about the "works of creation" (KU, AA v 383.36); in $\S 80$ he points to "the great creation of organized natures» (KU, AA v 418.18-19). In $\S 82$ Kant describes the human being as "final end of creation" (KU, AA v 426.16) and says that it is "the ultimate end of the creation here on earth" (KU, AA v 426.37); in the heading of $\S 84$ Kant asks for "the final end of the existence of a world, i.e., of creation itself» (KU, AA v 434.5-6). ${ }^{2}$ Kant defines the notion of 'creation' as «the cause of the existence of a world or of the things in it (substances)" similar to what is implied in the wording "actuatio substantiae est creatio"; and even though, he says, the presupposition of creation - a creator, a "freely acting and consequently intelligent cause» (KU, AA v 449.34-39) - is not already implied by the word 'creation' since it needs additional proofs of the existence of God, Kant delivers these proofs in $\$ \S 85-91$ of the Critique of the Power of Judgment. I think the best way to understand Kant's claim that the supersensible is a ground for our human judgment and for nature as it appears to us is that Kant accepts the regulative ideas of creation and a creator.

Kant's lectures on rational theology hint at slightly different type of answer as to what extent the supersensible is a ground for our human point of view: Kant there describes the relationship between our human and the divine understanding such that it is not a contingent one. God's understanding is not entirely different from ours; it is just not restricted and limited as ours. If we free our understanding from its limitations we can imagine the form and content of a divine understanding, and in turn,

passage Kant does not point to his own concept of a divine artisan, but to traditional arguments against the physicotheological proof of the existence of God.

${ }^{1}$ E. Förster, Die Bedeutung von $\oint \oint 76,77$ der Kritik der Urteilskraft für die Entwicklung der nachkantischen Philosophie, Teil I-II; Von der Eigentümlichkeit unseres Verstandes; M. Frank, V. Zanetti, Dialektik der teleologischen Urteilskraft.

${ }^{2}$ Further references to the term 'creation' can be found in $\S 85$ ( $\left.K U, \mathrm{AA} v 437.19\right)$; in $\S 86$ (KU, AA v 442.21, 31; $K U$, AA v 443.1, 16, 23, 34-35; $K U, \mathrm{AA} v$ 444.2; $K U$, AA v 445.8-9); in $\S 87$ (KU, AA v 449.16, 34; $K U$, AA v 452.29); in $\S 88(K U, A A v 453.29,32 ; K U, A A v 454.10,13,24 ; K U, A A v 455.1-2,12,15-16,31-32 ; K U, A A v 456.15)$; in $\S 90$ ( $K U, \mathrm{AA} v$ 463.26); and in $\S 91$ (KU, AA v 469.30). 
not before we posit God as necessary maximum of insight and reality we can think of a less extended, limited understanding like ours and the possibility of things as they appear to us (V-Th/Volckmann, AA xviII/2.2 1158.25-39). As already mentioned above, Kant thinks that the faculties of sensibility and reason restrict our understanding to its empirical and discursive use. God's purely intuitive understanding, in contrast, has an immediate insight into originaria, original intuitions:

We must have a maximum, and we cannot otherwise reach it as by a removal of all limitations. Let us say: Our understanding cannot conceive of things otherwise than by universal features. This, however, is a limitation of the human understanding, which cannot happen in God. For this reason we imagine a maximum of an understanding, i.e., an intuitive understanding.

$$
\text { (V-Phil-Th/Pölitz, AA xxvıiı/ } 2.2 \text { 996.18-24) }{ }^{1}
$$

Another argument for the grounding force of the intuitive understanding is that only the intuitive understanding can represent (and generate) an order in which the real whole precedes the parts, i.e., for which ideas of purposes are prior to the parts and are real. Our theoretical understanding, which is committed to go from the part to the whole, and thus, also our theoretical reason, inferring ideas (e.g., purposes) from our concepts of understanding, cannot represent a real purpose, since for a purpose it would be required to go from a whole, which is prior, to the parts. Only an intuitive understanding can generate a real purpose, and the capacity to comprehend the possibility of purposes for us depends on the reality of purposes in God's understanding.

It remains to be said how our understanding unifies the two kinds of laws of nature. Here, I agree with the analyses of current interpreters like Ginsborg (2006), Breitenbach (2009), Quarfood (2014), ${ }^{2}$ and others who say that $\S 78$ offers the most compelling argument for the arrangement of the two kinds of laws in our human understanding. Kant describes this unification of the two kinds of theoretical laws of nature, of mechanism and teleology as a means-end-relationship (KU, AA v 414.12-13, 27; $K U, A A v$ 414.37-415.1) whereby mechanical laws serve as "subordinated» (KU, AA v 414.9, 15, 27; KU, AA v 415.11, 22) means to super-ordinate teleological laws as their end:

For where ends are conceived as grounds of the possibility of certain things, there one must also assume means the laws of the operation of which do not of themselves need anything that presupposes an end, which can thus be mechanical yet still be a cause subordinated to intentional effects. Hence even in organic products of nature, but even more if [...] we assume that intentionality in the connection of natural causes in accordance with particular laws is also $[\ldots]$ the universal principle of the reflecting power of judgment for the whole of nature (the world), we can conceive a great and even universal connection of the mechanical laws with the teleological ones in the productions of nature, without confusing the principles for judging it with one another and putting one in the place of the other, because in a teleological judging of matter, even if the form which it assumes is judged as possible only in accord with

${ }^{1}$ See «Wir müssen aber das Maximum haben, und dies erhalten wir nicht anders, als durch Aufhebung aller Einschränkung, und sagen so: Unser Verstand kann nicht anders, als durch allgemeine Merkmale Dinge erkennen; dies ist aber eine Einschränkung des menschlichen Verstandes, und bei Gott kann diese nicht statt finden. Demnach denken wir uns das Maximum des Verstandes, d.i. einen anschauenden Verstand" (V-PhilTh/Pölitz, AA xxviıI/2.2 996.18-24).

${ }^{2}$ H. Ginsborg, Kant's Biological Teleology; A. Breitenbach, Die Analogie von Vernunft und Natur; M. QuaRFOoD, The Antinomy of Teleological Judgment: What It Is and How It Is Solved. 
an intention, still its nature, in accordance with mechanical laws, can also be subordinated as a means to that represented end.

(KU, AA v 414.12-27, italics partly added)

Kant confesses that he is not able to say how much mechanism can contribute as a means to the final end of nature, but that we shall try to explain nature as far as we can by mechanical laws since the determining laws of understanding alone allow an insight into nature for us (KU, AA v 414.36-415.22). ${ }^{1}$

\section{6. Arrived?}

Almost. In $\S \S 86-91$ Kant describes an ethico-theological notion of God whose capacity is not only to represent the unity of the theoretical laws of nature, that is, the unity of mechanical and teleological natural laws and the unity of a nature that follows these laws, but also the unity of the theoretical and practical laws, that is, the unity of the mechanical and teleological natural and the teleological moral laws, and the unity of a world that follows these laws (KU, AA v 444.12-15; KU, AA v 456.11-22). The regulative idea of God that we described above would already suffice to account for the unity of both kinds of natural laws. However, since for Kant, this aspect of God is only an aspect of a richer idea of God who represents the unity of natural and moral laws, it is ultimately this richest regulative idea of a theoretical intelligent, intentional and practical wise God, endowed with a consciousness, in which not only the theoretical, but also the theoretical and practical laws are one, that forms the supersensible ground of the unity of the mechanical and teleological higher order natural laws, and the unity of natural and moral laws.

\section{Abstract}

The antinomy of teleological judgment is one of the most controversial passages of Kant's Critique of the Power of Judgment. Having developed the idea of an explanation of organized beings by mechanical and teleological natural laws in $\S \S 61-68$, in $\S \S 69-78$ Kant raises the question of whether higher order mechanical and teleological natural laws, which unify the particular empirical laws of organized beings, might pose an antinomy of conflicting principles within the power of judgment. I will argue against alternative views that this antinomy is neither a conflict between objective constitutive principles of the determining power of judgment nor a conflict between an objective constitutive principle of the determining power of judgment and a subjective regulative maxim of the reflecting power of judgment nor does it consist in a confusion of a pair of subjective regulative maxims of the reflecting power of judgment with a pair of objective constitutive principles of the determining power of judgment, but does consist in an apparent conflict between mechanical and teleological natural laws as

\footnotetext{
1 Regarding the subordination of mechanism as a means under teleology as an end as a resolution of the antinomy for our human judgment, I agree with Quarfood (The Antinomy of Teleological Judgment) and Förster (Von der Eigentümlichkeit unseres Verstandes) that this thought reminds us of the resolution of the antinomy of practical reason in the Critique of Practical Reason rather than the resolution of the third antinomy in the Critique of Pure Reason, as McLaughlin (Kant's Critique of Teleology in Biological Explanation) claimed. In the resolution of the third antinomy in the Critique of Pure Reason Kant only argues for the possibility of a coexistence of the causalities of nature and freedom. In the resolution of the antinomy of practical reason, however, the principle of happiness is subordinated to the principle of the worthiness to be happy within the highest moral good $(\mathrm{KPV}, \mathrm{AA} \mathrm{v}$ 119.1-24). Within this relationship, happiness is thought to contribute to the final end of morality which resembles a means end relationship rather than a sheer coexistence.
} 
subjective regulative maxims of the reflecting power of judgment. I will further argue that Kant's resolution of the antinomy consists in the regulative idea of a supersensible that represents the unity of both kinds of natural laws and justifies the unification of both kinds of natural laws in the human power of judgment. Kant uses three notions when he talks about the supersensible - the regulative idea of a divine artisan, the regulative idea of a divine intuitive understanding, and the regulative idea of an underdetermined, supernatural ground of nature. I will show how each of these notions accounts for the unity of both kinds of natural laws and will discuss possible correlations between them. I will then explain how the unity of both kinds of natural laws in the regulative idea of a supersensible accounts for the unification of both kinds of natural laws in the human power of judgment. While the divine intuitive understanding is perfect and uncreated and, thus, capable of a representation of the unity of both kinds of natural laws, the human discursive understanding is imperfect and created; it is capable only of the representation of the unification of both kinds of natural laws in form of a hierarchy of laws. 
